\title{
The Investigation of Physical Performance Status of Visually and Hearing Impaired Applying Judo Training Program
}

\author{
Onder Karakoc \\ Correspondence: Onder Karakoc, School of Physical Education and Sport, Gaziantep University, Turkey. \\ Tel: +90 50503705256 \\ Received: February 23, 2016 \\ Accepted: February 27, $2016 \quad$ Online Published: March 3, 2016 \\ doi:10.11114/jets.v4i6.1399 \\ URL: http://dx.doi.org/10.11114/jets.v4i6.1399
}

\begin{abstract}
It was aimed to investigate the physical performances of visually and hearing impaired doing judo training in this study. 32 male athletes, who were doing judo training, volunteer and, visually and hearing impaired, participated in this study. The investigation was applied to visually impaired $(\mathrm{N}=12$, mean $\pm \mathrm{SD}$; age: $25.75 \pm 3.55$ years, height: $169.50 \pm 9.41$ $\mathrm{cm}$, weight: $74.17 \pm 20.17 \mathrm{~kg}$, sport age: $6.42 \pm 1.62)$ and hearing impaired $(\mathrm{N}=20$, mean $\pm \mathrm{SD}$; age: $19.25 \pm 5.70$ years, height: $172.55 \pm 7.58 \mathrm{~cm}$, weight: $70.55 \pm 11.12 \mathrm{~kg}$, sport age: $5.85 \pm 1.60$ ) male judoka.

Flamingo balance test score averages for study groups were detected as $8.00 \pm 3.27 \mathrm{~min} / \mathrm{pc}$ in visually impaired male judoka and $13.50 \pm 3.08 \mathrm{~min} / \mathrm{pc}$ in hearing impaired male judoka. There was a significant association between two groups in favor of visually impaired judoka $(\mathrm{p}<0.05)$. As a result of the evaluation conducted, push-up performances in $30 \mathrm{~s}$ were measured as $35.92 \pm 7.19 \mathrm{~min} / \mathrm{pc}$ for visually impaired judoka and $29.55 \pm 7.74 \mathrm{~min} / \mathrm{pc}$ for hearing impaired judoka. Flexibility values were found $-3.17 \pm 8.81 \mathrm{~cm}$ for visually impaired judoka and $2.50 \pm 3.37 \mathrm{~cm}$ for hearing impaired judoka. According to $30 \mathrm{~s}$ push-up and flexibility value averages, there was a significant association in hearing impaired male judoka $(\mathrm{p}<0.05)$.

Also, as a result of performed test value averages, there was no significant relationship in leg strength, vertical jump, right and left hand grip strength, $30 \mathrm{~s}$ sit-up and body fat percentage values ( $p>0.05)$.

In conclusion, it is thought that there is no negative effect of vision and hearing impairment factors on physical performance levels due to the close proximity of training levels of the elite judoka and also there is more development in balance variables in visually impaired when compared to hearing impaired due to the properties of impairment degree.
\end{abstract}

Keywords: Judo, training, visually impaired, hearing impaired, physical performance

\section{Introduction}

Judo is one of the sport branches which impaired children can also do in the World. Visually, hearing and trainable mentally impaired are also capable of doing judo for the purpose of rehabilitation.

Judo provides self-discipline and respect for individuals doing it. Self-confidence, balance, concentration, leadership skills is a way to gain physical fitness as well as mental development (Karakoc, 2014b). Judo is an Olympic sport that requires a high level in terms of technique, tactic and physical fitness (Little, 1991). Technical and tactical features, which have high-intensity violence, are dynamic and have many complex skill features, occupy an important place for success in Judo (Callister, 1991).

Judoka have to maintain optimal performance throughout the year. This depends on several factors. Therefore, it is important the properties like strength, aerobic capacity, anaerobic power, speed, flexibility, balance and coordination to be developed by judo-specific training in addition to technical and tactical trainings (Karakoc, 2014a). Moreover, excellent level of fitness, physical endurance and high level of muscle strength also play an important role in order to get success in international championships (Franchini, 2011). Cardiovascular endurance, muscle strength, flexibility and balance are known to be lower in visually impaired individuals when compared to healthy individuals (Skaggs, 1996). There are different studies in the literature about judo and exercise.

Visually impaired individuals need more support in the physical and psychological development. When healthy and visually impaired individuals are compared, it is observed that physical and psychological development is weaker in 
visually impaired (Lieberman, 2001). Sport and exercise are made by impaired individuals in order to provide benefits for their quality of life. However, impaired individuals can not have the opportunities as sedentary individuals.

The idea is advocated that the delay in the motor development in visually impaired individuals stems from the lack of experience rather than the loss of ability, and they should move in a suitable environment provided and need to be motivated to participate in physical activity (Capps, 1996). However, it is necessary to provide high-level motor performance and protect and maintain static and dynamic balance in order to ensure successful performance in sport events (Erkmen, 2007). Regulation in the context of compliance in applied fields requiring motor skills is made to the individuals who are lack of motor skills according to disability degrees (Meydan, 2009). Physiological fatigue starts to emerge in impaired individuals after physical activities. Therefore, postural control is seen to fall. Fatigue occurring during training begins to prevent the desired performance level. Injuries can be seen together with the loss of balance (Nokes, 2000).

Researchers investigate psychological, physiological and physical values which are necessary in senior athletes. It is thought that the investigation and knowledge of the differences in levels of physical, mental and motoric developments between impaired and non-impaired individuals have an important place in terms of training plans to be implemented. Thus, the aim of this study is to investigate physical performance parameters of visually and hearing impaired judoka making judo actively.

\section{Materials and Methods}

32 visually and hearing impaired volunteer athletes, who were experienced judokas, applying judo training programs for $90 \mathrm{~min} / 3$ days in a week were participated to the study and judo training programs lasted 12 weeks. 32 male athletes, who were doing judo training, volunteer and, visually and hearing impaired, participated in this study. The investigation was applied to visually impaired $(\mathrm{N}=12$, mean $\pm \mathrm{SD}$; age: $25.75 \pm 3.55$ years, height: $169.50 \pm 9.41 \mathrm{~cm}$, weight: $74.17 \pm$ $20.17 \mathrm{~kg}$, sport age: $6.42 \pm 1.62)$ and hearing impaired $(\mathrm{N}=20$, mean $\pm \mathrm{SD}$; age: $19.25 \pm 5.70$ years, height: $172.55 \pm$ $7.58 \mathrm{~cm}$, weight: $70.55 \pm 11.12 \mathrm{~kg}$, sport age: $5.85 \pm 1.60)$ male judoka. Visually impaired judoka participated to this study had B3 degree of visual impairment and hearing impaired judoka had hearing disability higher than $55 \mathrm{Db}$.

It was determined for the study groups whether there was a severe injury within the last 6 months by asking in the context of a questionnaire by sign language interpreters for the hearing impaired. A document stating that they were volunteer and informed about the tests to be applied in the study was given to the study groups and their signatures were obtained.

The study was conducted in the sports hall of Physical Education and Sports School in Gaziantep University. The tests in the study were applied in the term of general preparation period training program of athletes.

\subsection{Measurements Protocols}

\subsubsection{Height}

Height measurements were done by the stadiometer (SECA, Germany) having $0.01 \mathrm{~m}$ degree of precision according to the measurement techniques (Gordon, 1988).

\subsubsection{Weight}

The feet of subjects were naked and without shoe, they wore only shorts and T-shirts and their weights were measured by electronic scale (SECA, Germany) having $0.1 \mathrm{~kg}$ degree of precision (Gordon, 1988).

\subsubsection{Balance (Flamingo Balance Test - FBT) (Number of Falls)}

Flamingo Balance Test was used to determine the static balance of hearing impaired and visually impaired judokas identified in the study. The study group was taken to the test after prepared with a 10-minute warm-up and stretching exercises with sportswear on the treadmill. Athletes come on the balance board, of which dimensions are $50 \mathrm{~cm}$ long, 3 $\mathrm{cm}$ wide and $4 \mathrm{~cm}$ height, with their dominant legs and try to stay in balance. They twist the other leg from the knee and hold it with the hand in the same directions by twisting towards the hip. They stay in balance for one minute. If they release the foot held or touch to the ground by falling down the board, the time is stopped. When the athletes come on the balance board and ensure the balance again, the time is again continued from where it leaves off. The test is applied for one-minute. When the time is off, the loss of ensuring the balance of each subject is counted after the test is completed and numerical value is recorded as the balance score (Tamer, 2000).

\subsubsection{Leg Strength Measurement}

The leg dynamometer, of which brand name was "Takei", measuring the leg strength was used in this study. Participants put their foot on the dynamometer table while the knees are in bent condition, hold their arms stretched, hold their knees bent at an angle of $130-140^{\circ}$, hold their back straight and the body bent slightly forward and pulls up the dynamometer 
stick grasped by their hands vertically by using their legs at a maximum rate. Relative leg strength $=$ force $/$ body weight (Özer, 2001).

\subsubsection{Vertical Jumping}

Jump-meter, of which brand name was Takai, was used in in the vertical jump test of the athletes. Jumping was applied as a complete jump upwards when the knees were in the squat position at 900 flexion and the hands were on the waist. Each measurement was repeated three times and the best value was recorded (Açıkada, 2008). Two minutes rest was given between each trial.

\subsubsection{Hand Grip Strength Measurements}

Hand grip strength was measured with the dynamometer (digital, Takei). During the measurement of each athlete, the dynamometer was calibrated and set according to the athlete's hand and finger properties. Force measurements were repeated twice. Measurements were performed so that the other arm, which was not measured, didn't get from anywhere. Two attempts were performed and better force value was recorded in kilograms (Tamer, 2000).

\subsubsection{Push-up Test}

Athletes lay on the ground while their faces were facing the ground, their feet were stretched from the knee and pushed their bodies up and down in tense situation in the knee without touching the ground while the body weight were on the foot ends and arms. Push-up count repeated within 30 seconds was recorded to the information form (Sevim, 1997).

Hand stopwatch having 1/1000 precision was used for $30 \mathrm{sec}$ push-up test of the athletes. Push-up was applied to the athletes with the start command for 30 seconds.

\subsubsection{Sit-up Test}

Hand stopwatch having 1/1000 precision was used for $30 \mathrm{sec}$ sit-up test of the athletes. After athletes lay on their back, bent knees, put their hands on neck and touched their foot bases on the ground, they performed sit-up for 30 seconds with the start command until they could repeat. The feet was held in order to prevent the feet disconnect contact from the ground during sit-up. It was carefully followed whether athletes' shoulders touched to the ground while they lay on the ground and their elbows touched to their knees while they straightened. Sit-up count repeated within 30 seconds was recorded to information form (Özer, 2001).

\subsubsection{Flexibility Test}

Flexibility measurements of the subjects were realized by sitting and reaching test using flexibility stand. The subjects sit, placed their feet to the base vertically while fingertips were on horizontal face edge, opened their feet shoulder-width apart and extended completely, bent their bodies forward as possible without bending the knees, stretched their hands and measurement was realized by pushing ruler gently. Three repeat was made and the highest result was recorded (Günay, 1994).

\subsubsection{Measurement of Subcutaneous Fat Ratio as Percentage (\%)}

Skinfold thickness measurements were performed using skinfold caliper (Holtain, UK) which applied $10 \mathrm{~g}$ pressure to 1 $\mathrm{mm}$ at each opening with error $\pm 2 \mathrm{~mm}$. Skinfold thickness measurements were performed from triceps, subscapula, suprailiac and abdomen regions and measurements were taken from the right side of the subjects. In skinfold thickness measurements, subcutaneous fat layer thickness between forefinger and thumb was drawn up slightly enough to leave the muscle tissue. Caliper was placed about $1 \mathrm{~cm}$ away from fingers and subcutaneous fat layer thickness held was read fromthe indicator on the caliper within 2-3 seconds and then was recorded in millimeters. Test-retest reliability coefficient of skin fold thickness and the total measurement error were determined. Yuhasz formula was used to determine the fat percentage of the subjects (Zorba, 1995).

\subsection{Judo Training Program}

There is a table below about judo training program. It continued three times a week and every training lasted 90 minutes. Judo training program was applied to visually and hearing impaired judokas. 
Table 1. Judo training program

\begin{tabular}{|c|c|}
\hline & Week \\
\hline Monday & $\begin{array}{ll}10 \mathrm{~min} . \text { warm up } \\
10 \mathrm{~min} . \text { special warm up } \\
2 \mathrm{~min} . \text { rest } \\
2 \times 10 \text { min uchi-komi (repeat technic) } \\
3 \text { min. rest } \\
2 \times 10 \text { min Nage Waza } \\
5 \text { min. rest } \\
5 \times 1 \text { min Nagekomi } \\
5 \text { min rest } \\
10 \text { min. streching } & \end{array}$ \\
\hline Wednesday & $\begin{array}{l}10 \mathrm{~min} . \text { warm up } \\
10 \mathrm{~min} \text {. special warm up } \\
2 \mathrm{~min} . \text { rest } \\
2 \times 10 \text { min Ne wazauchi-komi (repeat technic) } \\
3 \mathrm{~min} . \text { rest } \\
4 \times 5 \min \mathrm{Ne} \text { Waza technic } \\
5 \mathrm{~min} \text { rest } \\
2 \times 5 \text { min Ne wazarandori } \\
10 \text { min. stretching }\end{array}$ \\
\hline Friday & $\begin{array}{l}10 \text { min. warm up } \\
10 \text { min. special warm up } \\
2 \text { min. rest } \\
2 \times 10 \text { min uchi-komi (repeat technic) } \\
3 \text { min. rest } \\
2 \times 5 \text { min Nage Waza technic } \\
2 \text { min rest } \\
3 \times 5 \text { min Nage Waza Randori } \\
3 \text { min rest } \\
15 \text { min. stretching }\end{array}$ \\
\hline
\end{tabular}

\subsection{Data Analysis}

Statistical analysis was performed using SPSS 16.0 software package. Statistical results were evaluated with $95 \%$ confidence interval and at $\mathrm{p}<0.05$ and $\mathrm{p}<0.01$ significance levels. Due to the fact that measurements of the groups showed normality and homogeneous distribution, Independent Samples T-Test was used for the analysis of the differences between visually and hearing impaired judoka.

\section{Results}

Table 2. Mean values and standard deviation of age, height, weight and sport age for visually and hearing impaired

\begin{tabular}{|c|c|c|c|c|}
\hline Variables & Visual impairment $(\mathrm{N}=12)$ & \multicolumn{3}{|c|}{ Hearing impaired $(\mathrm{N}=20)$} \\
\hline Age (years) & $25.75 \pm 3.55$ & \multicolumn{3}{|c|}{$19.25 \pm 5.70$} \\
\hline Height $(\mathrm{cm})$ & $169.50 \pm 9.41$ & \multicolumn{3}{|c|}{$172.55 \pm 7.58$} \\
\hline Weight (kg) & $74.17 \pm 20.17$ & \multicolumn{3}{|c|}{$70.55 \pm 11.12$} \\
\hline Sport age (years) & $6.42 \pm 1.62$ & \multicolumn{3}{|c|}{$5.85 \pm 1.60$} \\
\hline \multicolumn{5}{|c|}{ Table 3. Comparison of visually and hearing impaired with respect to variables } \\
\hline Variables & Visual impairment & Hearing impairment & $\mathrm{T}$ & $P$ \\
\hline Balance (number of falls) & $8 \pm 3.27$ & $13.50 \pm 3.08$ & 4.836 & $0.000 *$ \\
\hline Leg strength $(\mathrm{kg})$ & $154.95 \pm 19.50$ & $150.28 \pm 32.56$ & 0.449 & 0.656 \\
\hline Vertical jumping (cm) & $37.08 \pm 5.32$ & $40.40 \pm 8.17$ & 1.252 & 0.220 \\
\hline Hand grip right hand $(\mathrm{kg})$ & $43.53 \pm 8.45$ & $40.66 \pm 8.24$ & 0.946 & 0.352 \\
\hline Hand grip left hand $(\mathrm{kg})$ & $45.67 \pm 8.08$ & $40.83 \pm 8.61$ & 1.576 & 0.126 \\
\hline Push up 30 sn (reps) & $35.92 \pm 7.19$ & $29.55 \pm 7.74$ & 2.312 & $0.028 *$ \\
\hline Sit-up30 sn (reps) & $25.83 \pm 4.22$ & $24.40 \pm 3.75$ & 0.970 & 0.343 \\
\hline Flexibility (cm) & $-3.17 \pm 8.81$ & $2.50 \pm 3.37$ & 2.600 & $0.014 *$ \\
\hline Body fat $\%$ & $15.45 \pm 3.84$ & $14.08 \pm 1.24$ & 1.488 & 0.147 \\
\hline
\end{tabular}

*p $<0.05$

Table 3 shows balance, push up, and flexibility was significantly different between visually and hearing impaired judoka. Visually impaired judoka was better than hearing impaired judoka in terms of balance and push up performance. Also, hearing impaired judoka was better than visually impaired judoka in flexibility performance. On the other hand, leg strength, vertical jump, hand grip right hand, hand grip left hand, sit-up and body fat percentage were insignificantly different between visually and hearing impaired judoka. 


\section{Discussion and Conclusion}

This study was conducted in order to evaluate the physical performances of visually and hearing impaired judoka making judo training.

The means of flamingo balance test scores for the study groups were detected $8.00 \pm 3.27 \mathrm{~min} / \mathrm{pc}$ invisually impaired male judoka and $13.50 \pm 3.08 \mathrm{~min} / \mathrm{pc}$ in hearing impaired male judoka. A significant association was observed for the difference between two groups in favor of visually impaired judoka $(\mathrm{p}<0.05)$. As a result of the evaluation performed, 30 second push-up values were determined $35.92 \pm 7.19 \mathrm{~min} / \mathrm{pc}$ for visually impaired judoka and $29.55 \pm 7.74 \mathrm{~min} / \mathrm{pc}$ for hearing impaired judoka. Flexibility values were found $-3.17 \pm 8.81 \mathrm{~cm}$ for visually impaired judoka and $2.50 \pm 3.37$ $\mathrm{cm}$ for hearing impaired judoka as a result of the evaluation performed. There was a significant association for hearing impaired male judoka as a result of mean 30 second push-up and flexibility values ( $\mathrm{p}<0.05)$.

In addition, there was no significant association for leg strength, vertical jump, right and left hand grip strength, 30 seconds sit-up and body fat percentage values as a result of test values performed $(p>0.05)$.

Yağc1 et al found in the study performed on healthy children and hearing impaired children that there was a significant increase in the level of balance skills in the group composing of healthy children, and the lowest significance was detected in the group of hearing impaired $(p<0.001)$. The data obtained from this study showed that hearing impairment negatively affected balance and movement system skills (Yağc1, 2004).

In the study, there was a significant difference for the means of the balance performance values in favor of visually impaired athletes. This difference in favor of visually impaired judo group comes from different training programs applied and is related to the diversity of impairment. It is thought that continuous balance ensuring tendency and posture control develop in visually impaired due to risk factors.

Balance problem in $90 \%$ of hearing impaired athletes is caused by problems occurring in the inner ear and the lack of coordination is seen in these individuals (Ministry of Family and Social Policies, 2013).

Balance is an important factor to maintain body composition and sports success. It is the basis of the movement for especially dynamic sports containing sudden movements and sports made with movement. Balance performance is required for all sports (Eler, 1996).

In the study conducted in order to investigate the association between maximum $\mathrm{VO}_{2}$ levels and balance scores of the young athletes, flamingo balance test average scores of young male athletes were detected as $6,72 \pm 4,27$ points $(\mathrm{p}<0,05)$ (Taskın, 2015). Especially from the investigation of sports related to the balance, the presence of more positive results in individual sports is thought to be resulted from balance trainings in training methods performed. More balance performance status of visually impaired athletes when compared to hearing impaired athletes in our study provided their performances increase significantly due to their impairment status.

They could not find any significant difference in females for the test results in the study conducted for balance and reaction parameters in hearing impaired and hearing non-impaired male and female children however male hearing impaired obtained higher values of balance test when compared male hearing non-impaired (Wieczorekve Zajqc, 2008).

This study shows parallelism to our study. The high value of the balance tests in individuals with hearing impairment indicates the number of errors is high. Accordingly, performance status seems to be better in visually impaired athletes when compared to hearing impaired athletes

Rajendran et al found in the study performed on the effect of training program in hearing impaired children that training program affected visual motor skills and were effective in eliminating the lack of vestibular system-related deficiencies (Rajendran, 2013)

Karakoç et al stated in their study that regular training of balance and coordination increased performances of hearing impaired athletes and static and dynamic balance training affected their performances (Karakoc, 2014). Studies in the literature suggest that training provides development. Muscle strength is important in maintaining of balance. Balance and all motor skills can be maintained via judo training.

While a significant difference was detected in favor of non-impaired group in terms of body weight, back strength, leg strength, vertical jump and aerobic strength in a study comparing the physical and physiological characteristics of impaired and non-impaired groups, the difference was observed in average height measurements in favor of impaired group (Iş̧1k, 2013).

It was found in a study realized that motor skills of hearing impaired children were weaker than hearing non-impaired children according to teacher reports and MABC (Movement Assessment Battery for Children) test results (Batya, 2009). It was specified in another study that motor characteristics of hearing impaired children and hearing non-impaired children varied considerably depending on the age (Boyd, 1967). 
In a study on the evaluation of the strength profiles of Finnish judoka, leg strength averages were found as $185.1 \pm 25$ $\mathrm{kg}$ in international judoka, $166 \pm 32.7 \mathrm{~kg}$ in national judoka and $140 \pm 36 \mathrm{~kg}$ in recreational judoka (Fagerlund, R. \& Hakkinen, H., 1991).

Franchini et al found in their study named as physical fitness and anthropometric profile of Brazilian male judo team that leg strength average was $104 \pm 27 \mathrm{~kg}$ for male judo a team and $104 \pm 18 \mathrm{~kg}$ for male judo reserve team (Franchini, E., Del Vecchio, F. B., Matsushigue, K. A., \& Artioli, G. G. 2011).

The mean values of vertical jump tests were found $57.61 \pm 7.30 \mathrm{~cm}$ in MMA male athletes and $60.00 \pm 10$ in wrestlers in a study conducted on physiological profiles of athletes doing martial arts (Gochioco, M. K., 2010).

The mean test values in a study applied on 20 male judoka and investigating the effects of judo competitions on muscle damage and fatigue were observed $45.38 \pm 5.24 \mathrm{~cm}$ before competitions and $44.96 \pm 5.56 \mathrm{~cm}$ after competitions (Detanico, D., Dal Pupo, J., Franchini, E., \& dos Santos, S. G., 2015).

The mean values of vertical jump were detected $49.00 \pm 5.00 \mathrm{~cm}$ in the test group and $48.00 \pm 4.00 \mathrm{~cm}$ in the control group in a study conducted on male athletes of wrestling which is one of the combat sports (Akbal, M., 1998).

Franchini et al (2005) found in their study done on elite and non-elite judoka that the right and left hand grip strength averages were $51.01 \pm 10.0 \mathrm{~kg}$ and $49.01 \pm 10.0 \mathrm{~kg}$ in elite judoka, respectively and the right and left hand grip strength averages were $42.01 \pm 11.0 \mathrm{~kg}$ and $40.01 \pm 10$.0in non-elite judoka, respectively (Franchini, E., 2005).

Thomas et al detected in their study performed on physiological profile of Canadian judo national team that the right and left hand grip strength averages of judoka were $56.41 \pm 6.6 \mathrm{~kg}$ and $55.71 \pm 6.6 \mathrm{~kg}$ (Thomas, S. G., Cox, M. H., LeGal, Y. M., Verde, T. J., \& Smith, H. K. 1989).

Little and Ne1l found in their study that the right and left hand grip strength averages were $52.01 \pm 8.3 \mathrm{~kg}$ and $50.61 \pm$ $8.5 \mathrm{~kg}$ in young men, respectively and the right and left hand grip strength averages were $57.71 \pm 9.0 \mathrm{~kg}$ and $54.01 \pm$ 10.4 in adult men, respectively (Little, N. G. 1991).

It was indicated in many studies that grip strength was very effective in judo sport. Grip strength takes extremely important place in judo training due to the fact that there are intense exercises and challenges associated with keeping the dress. Intensity, duration, intensity, and training model of the trainings in especially preparation period affect the athletes' performance levels.

Taylor et al found in their study on the Canadian judo team that push-up average of men's team was $72 \pm 16$ (Taylor, A. W. \& Brassard, L. 1981). In a study conducted by Krstulović et al and named as biomotor system in young elite judoka, push-up average of men's team was found as $56 \pm 8$ (Krstulović, S., Žuvela, F. \&Katić, R. 2006).

In a study conducted on hearing impaired athletes for $30 \mathrm{sec}$ push-up test, pre-test and post-test averages were found $21.33 \pm 9.35$ reps and $22.67 \pm 9.43$ reps for the control group, respectively and pre-test and post-test averages were found $24.73 \pm 9.50$ reps and $27.47 \pm 10.26$ reps for the test group, respectively (p>0.05) (Karakoç O., 2014a).

When we compare our study results with the results of other studies, it can be said that the reason of the difference between them arises from the fact that the athletes in our study were active and elite athletes, had different impairment status and were subjected to the different training programs.

Judoka were classified as light, medium and heavy weight in a study performed by Krstulovic S. in order to evaluate the performances of male judo athletes. The flexibility test averages were found as $4.79 \pm 1.23 \mathrm{~cm}$ for light weight judoka, $5.28 \pm 0.95 \mathrm{~cm}$ for medium weight judoka and $5.41 \pm 0.98 \mathrm{~cm}$ for heavy weight judoka (Krstulović, S., 2012).

In a study conducted by Karakoc O. on balance training of hearing impaired judoka, pre-test and post-test flexibility averages were found $8.53 \pm 4.37 \mathrm{~cm}$ and $9.33 \pm 5.08 \mathrm{~cm}$ for the control group, respectively and pre-test and post-test flexibility averages were found $12.67 \pm 7.24 \mathrm{~cm}$ and $13.20 \pm 6.72 \mathrm{~cm}$ for the test group, respectively. There was no significant difference between pre-test and post-test flexibility values in the test group ( $p>0.05)$ (Karakoc, 2014a).

Flexibility is the ability to move of the joint or joint series at wide angle. For this reason, flexibility is of great importance not only for sport success and performance but also in terms of prevention of injuries (Doğan, 1991).

A high level of flexibility value is needed in judo in order to do a wide variety of techniques at very wide angles and in accordance with the original motion (Knobloch, et.al., 2005).

It was found in the study performed on Brazilian men's judo team in order to evaluate their physical fitness and anthropometric profiles that body fat percentages were $8.9 \%$ in Hungary team, $12.3 \%$ in Canada team, $16.2 \%$ in Japan team, $13.7 \%$ in Brazil team and $8.3 \%$ in North America team (Franchini, E., Nunes, A. V., Moraes, J. M., \& Del Vecchio, F. B. 2007).

In a study performed on body anthropometric profiles according to the levels of judoka in judo specific fitness test, 
judoka doing judo for less than five years were classified as group A and judoka doing judo for more than five years were classified as group B. Body fat percentage averages were found as $11.9 \%$ and $13.8 \%$ for the groups A and B, respectively (Katralli, J., \& Goudar, S., 2012).

Strong decreases in the values of body weight, body fat percentage (BFP), body fat (BF) and lean body mass (LBM) of the test group were obtained after submaximal aerobic exercise applied to young male individuals for 8 weeks in another study (Daglioglu O., 2013).

The fact specified in several studies in the literature that exercise is effective in the development of motor skills in impaired individuals is important in terms of showing parallelism with our study.

All in all, it is thought that visually and hearing impairment factors don't have a negative effect on physical performance levels due to the fact that exercise levels of elite judoka are similar to each other and also balance variable shows more development in visually impaired compared to hearing impaired.

\section{References}

Açıkada, C. (2008). Atletizm Yetenek Modeli Raporu. Atletizm Federasyonu Eğitim Kurulu Yayınları II., Ataofset Matbacilik.

Aile, T. C., \& Bakanlığı, S. P. (2013). Engelli ve Yaşlı Hizmetleri Genel Müdürlüğü, Sıkça Sorulan Sorular, Engelli Bakım Hizmetleri, Ankara.

Akbal, M. (1998). Güreşçilerde hazırlık dönemi antrenman programları içerisinde fiziksel çalışmaların kassal kuvvet üzerine etkileri (Doctoral dissertation, Selçuk Üniversitesi Sağllk Bilimleri Enstitüsü).

Boyd, J. (1967). Comparison of motor behavior in deaf and hearing boys. American annals of the deaf.

Callister, R., Callister, R. J., Staron, R. S., Fleck, S. J., Tesch, P., \& Dudley, G. A. (1991). Physiological characteristics of elite judo athletes. International Journal of Sports Medicine, 12(2), 196-203. http://dx.doi.org/10.1055/s-2007-1024667

Capps, L., Sigman, M., Sena, R., Heoker, B., \& Whalen, C. (1996). Fear, anxiety and perceived control in children of agoraphobic parents.Journal of Child Psychology and Psychiatry, 37(4), 445-452. http://dx.doi.org/10.1111/j.1469-7610.1996.tb01425.x

Daglioglu O. (2013).The effect of 8-week submaximal aerobic exercise on cardiovascular parameters and body composition in young men. International Journal of Academic Research Part A; 5(4), 210-216. http://dx.doi.org/10.7813/2075-4124.2013/5-4/a.29

Detanico, D., Dal Pupo, J., Franchini, E., \& dos Santos, S. G. (2015). Effects of successive judo matches on fatigue and muscle damage markers. The Journal of Strength \& Conditioning Research, 29(4), 1010-1016. http://dx.doi.org/10.1519/jsc.0000000000000746

Doğan, A. A., \& Zorba, E. (1991). EsnekliğinGeliştirilmesindeKullanılanFarklıEsnetmeTekniklerininEtkinliği. HA Ĕ̈itimFakültesiSporBilimleriDergisi, 2(4), 41-48.

Eler, S., Yıldıran, İ., \& Sevim, Y. (1996). Bir sezonluk Antrenman Periyotlaması boyunca üst düzey erkek hentbolcuların bazı motorik ve fizyolojik parametrelerinin incelenmesi. Gazi Üniversitesi, Sağlık Bilimleri Enstitüsü, Yayınlanmamış Y. Lisans Tezi, Ankara, 6-12.

Engel-Yeger, B., \& Weissman, D. (2009). A comparison of motor abilities and perceived self-efficacy between children with hearing impairments and normal hearing children. Disability and rehabilitation, 31(5), 352-358. http://dx.doi.org/10.1080/09638280801896548

Erkmen, N., Suveren, S., Göktepe, A. S., \& Yazıcıŏlu, K. (2007). Farklı branşlardaki sporcuların denge performanslarının karşılaştırılması. Spormetre Beden Eğitimi ve Spor Bilimleri Dergisi, 3, 115-12. http://dx.doi.org/10.1501/sporm_0000000080

Fagerlund, R., \& Hakkinen, H. (1991). Strength Profile of Finnish Judoists-Measurement and Evaluation, Biology of Sport, 8(3), 143-149.

Franchini, E., Del Vecchio, F. B., Matsushigue, K. A., \& Artioli, G. G. (2011). Physiological profiles of elite judo athletes. Sports Medicine, 4l(2), 147-166. http://dx.doi.org/10.2165/11538580-000000000-00000

Franchini, E., Nunes, A. V., Moraes, J. M., \& Del Vecchio, F. B. (2007). Physical fitness and anthropometrical profile of the Brazilian male judo team. Journal of physiological anthropology, 26(2), 59-67. http://dx.doi.org/10.2114/jpa2.26.59

Franchini, E., Takito, M. Y., Kiss, M. A. P. D. M., \& Strerkowicz, S. (2005). Physical fitness and anthropometrical differences between elite and non-elite judo players. Biology of Sport, 22(4), 315. 
Gochioco, M. K. (2010). Physiological profile of mixed martial artists. Calıfornı State Unıversity, Fullerton.http://dx.doi.org/10.1249/01.mss.0000386626.85052.ea

Gordon, C. C., Chumlea, W. C., \& Roche, A. F. (1988). Stature, recumbent length, and weight. Anthropometric standardization reference manual. Champaign: Human kinetics Books, 3-8.

Günay, M., Erol, A. E., \& Savaş, S. (1994). Futbolculardaki kuvvet, esneklik-çabukluk ve anaerobic gücün boy, vücut ağırlığı ve bazı antropometrik parametreler ile ilişkisi. Hacettepe Üniversitesi Spor Bilimleri Dergisi, Ankara,5, 3-11.Işık, A. (2013). İşitme Engelli Ve İşitme Engelli Olmayan Spor Yapan Çocukların Fiziksel Ve Motorik Özelliklerinin Karşılaştırılması (Doctoral dissertation, Niğde Üniversitesi).

Karakoc, O. (2014a). İşitme Engelli Judocularda Sekiz Haftalık Denge Ve Koordinasyon Antrenmanlarının Performans Üzerine Etkileri. Yayınlanmış Doktora Tezi.Fırat Üniversitesi, Sağlık Bilimleri Enstitüsü Beden Eğitimi ve Spor Anabilimdal1.

Karakoc, O. (2014b). Judo Ogreniyorum. Spor Yayınevi. 8-128.

Katralli, J., \& Goudar, S. (2012). Anthropometric profile and special judo fitness levels of Indian judo players. Asian journal of sports medicine, 3(2), 113. http://dx.doi.org/10.5812/asjsm.34710

Knobloch, K., Martin-Schmitt, S., Gösling, T., Jagodzinski, M., Zeichen, J., \& Krettek, C. (2005). Prospective proprioceptive and coordinative training for injury reduction in elite female soccer. Sportverletzung Sportschaden: Organ der Gesellschaft fur Orthopadisch-Traumatologische Sportmedizin, 19(3), 123-129. http://dx.doi.org/10.1055/s-2005-858345

Krstulović, S. (2012). Predictors of judo performance in male athletes, 14(2).

Krstulović, S., Žuvela, F., \& Katić, R. (2006).Biomotor systems in elite junior judoists. Collegium antropologicum, 30(4), 845-851.

Lieberman, L., \& McHugh, E. (2001). Health-related fitness of children who are visually impaired. Journal of Visual Impairment \& Blindness (JVIB), 95(05).

Little, N. G. (1991). Physical performance attributes of junior and senior women, juvenile, junior, and senior men judokas. The Journal of sports medicine and physical fitness, 31(4), 510-520.

Meydan, A. (2009). Sosyalbilgileröğretimindegezigözlemvedoğaeğitimi. R. Turan, AM Sünbülve H. Akdağ. Sosyalbilgileröğretimindeyeniyaklaşımlar, 1, 241-261.

Noakes, T. D. (2000). Physiological models to understand exercise fatigue and the adaptations that predict or enhance athletic performance. Scandinavian journal of medicine \& science in sports, 10(3), 123-145. http://dx.doi.org/10.1007/s001320050550

Özer, K. (2001). Fiziksel Uygunluk, Nobel Yayınları, 1. Baskı, Ankara.

Rajendran, V., Roy, F. G., \& Jeevanantham, D. (2013). Effect of exercise intervention on vestibular related impairments in hearing-impaired children. Alexandria Journal of Medicine, 49(1), 7-12 http://dx.doi.org/10.1016/j.ajme.2012.10.001

Sevim, Y. (1997). Antrenmanbilgisi. Tutibay Limited Şti.

Skaggs, S., \& Hopper, C. (1996). Individuals with visual impairments: A review of psychomotor behavior. Adapted Physical Activity Quarterly, 13, 16-26.

Tamer, K. (2000). Spordafiziksel-fizyolojikperformansınölçülmesivedeğerlendirilmesi. Bağırgan Yayımevi.

Taskın, C., Taskın, M., \& Guven, F. (2015). Relationship between balance and aerobic capacity in adolescent athletes. Turkish Journal of Sport and Exercise, 17(3), 27-31.

Taylor, A. W., \& Brassard, L. (1981). A physiological profile of the Canadian judo team. The Journal of sports medicine and physical fitness, 21(2), 160.

Thomas, S. G., Cox, M. H., LeGal, Y. M., Verde, T. J., \& Smith, H. K. (1989). Physiological profiles of the Canadian National Judo Team. Canadian journal of sport sciences.Journalcanadien des sciences du sport, 14(3), 142-147.

Wieczoek, M., \& Zajic, M. (2008). Zdolnosei Koordynaeyjne Dzieei Zdrowyeh I niestyszqcyeh, Annal. Univer. Mariae Curie-Sktodowska, 60:8/867, supl. 16,187-190.

Yağcı, N., Cavlak, U., \& Şahin, G. (2004). İşitme Engellilerde Denge Yeteneğinin İncelenmesi Üzerine Bir Çalışma. KBB Forum.

Zorba, E., \& Ziyagil, M. A. (1995). Vücut Kompozisyonu ve Ölçüm Metotları, Gen Matbaacılık, Trabzon.

\section{$(\mathrm{cc}) \mathrm{Br}$}

This work is licensed under a Creative Commons Attribution 3.0 License. 